E-JURNAL EKONOMI DAN BISNIS UNIVERSITAS UDAYANA
Available online at https://ojs.unud.ac.id/index.php/EEB/index
Vol. 10 No. 7, July 2021, pages: 574-589
e-ISSN: 2337-3067

\title{
STRATEGI PEMBANGUNAN ZONA INTEGRITAS
}

\section{Dodik Ari Cahyono ${ }^{1}$ IB Raka Suardana ${ }^{2}$}

Article history:

Submitted: 29 Maret 2021

Revised: 7 April 2021

Accepted: 27 April 2021

\section{Keywords:}

Human Capital;

Integrity;

\section{Kata Kunci:}

Sumber Daya Manusia;

Integritas;

\section{Koresponding:}

Universitas Pendidikan

Nasional, Bali, Indonesia

Email:

dodik.ari80@gmail.com

\section{Abstract}

This research aims to determine the organizational management strategy with all the capabilities and limitations of organizational resources in going beyond the twists and turns, sacrifices, obstacles and challenges in realizing the development of the integrity zone by implementing effective management and empowering potential employees. as human capital. Qualitative methods with triangulation techniques, namely interviews, field observations and document studies, with the research setting at the Office of Supervision and Service of Customs and Excise Type Madya Pabean Ngurah Rai. The data were analyzed against the interviewee's answers with secondary / supporting data obtained and verification of the validity / validity of the data was carried out with no difference between what the researcher reported and what actually happened to the object under study. In this study, it was found the intricacies of organizational efforts in implementing management in the form of work programs / strategies, innovation, empowerment of employees as human capital and the results of developing the integrity zone.

Abstrak
Penelitian ini bertujuan untuk mengetahui strategi manajemen
organisasi dengan segala kemampuan dan keterbatasan sumber daya yang
di miliki organisasi dalam melampui lika liku, pengorbanan, hambatan dan
tantangan dalam mewujudkan pembangunan zona integritas dengan
penerapan manajemen yang efektif dan memberdayakan potensi pegawai
sebagai human capital. Penelitian ini menggunakan metode kualitatif
dengan teknik triangulasi yaitu wawancara, observasi lapangan dan study
dokumen, dengan setting penelitian di Kantor Pengawasan dan Pelayanan
Bea dan Cukai Tipe Madya Pabean Ngurah Rai. Data dianalisis terhadap
jawaban yang diwawancarai dengan data sekunder/pendukung yang
diperoleh dan verifikasi keabsahan/valid data dilakukan dengan tidak
adanya perbedaan antara yang dilaporkan peneliti dengan apa yang
sesungguhnya terjadi pada obyek yang diteliti. Dalam penelitian ini
menemukan lika liku upaya Organisasi dalam menerapkan manajemen
berupa program kerja/ strategi, inovasi, pemberdayaan pegawai sebagai
human capital dan hasil dari pembangunan zona integritas.

Universitas Pendidikan Nasional, Bali, Indonesia ${ }^{2}$

Email: ajikraka@yahoo.com 


\section{PENDAHULUAN}

Birokrasi merupakan konsep organisasi pemerintahan yang mempunyai fungsi melaksanakan kebijakan-kebijakan yang berkaitan dengan fungsi pelayanan publik dan mensukseskan program-program pemerintah untuk mencapai tujuan kebijakan negara (Fatkhuri, 2018). Pasca Reformasi di Indonesia kurang lebih telah berlangsung 20 tahunan masih banyak tuntutan-tuntutan yang dilakukan oleh segenap lapisan masyarakat baik dalam bentuk lisan, orasi, dalam bentuk demonstrasi maupun dalam bentuk tertulis melalui media cetak, elektronik dan media sosial yang membuktikan masih banyaknya agenda-agenda reformasi yang belum sepenuhnya terwujud, khusunya dalam bentuk penegakan hukum, Hak asasi Manusia, pemberantasan Korupsi, Kolusi dan Nepotisme, serta pertumbuhan ekonomi yang belum merata dan belum meningkatkan kesejahteraan masyarakat, sedikitnya lapangan pekerjaan, meningkatnya harga-harga kebutuhan pokok dan pengurangan subsidi sehingga tantangan di bidang ekonomi ini memberikan beban tersendiri bagi pemerintah Indonesia (Pranoto, 2018) efektif dan efisien sehingga masyarakat dapat dilayani secara cepat, tepat, dan profesional, Reformasi birokrasi berusaha memperbaiki ribuan proses tumpang tindih antar fungsifungsi pemerintahan, melibatkan jutaan pegawai, dan memerlukan anggaran yang tidak sedikit. Selain itu, reformasi birokrasi juga berarti menata ulang proses birokrasi dari tingkat tertinggi hingga terendah dan melakukan terobosan baru dengan langkah-langkah bertahap, konkret, realistis, sungguhsungguh, berfikir di luar kebiasaan/rutinitas yang ada, perubahan paradigma, dan dengan upaya luar biasa (Dwiyanto, 2015 dalam Julia Hapsari, 2019).

Berdasarkan Peraturan Presiden Nomor 81 Tahun 2010 tentang Grand Design Reformasi Birokrasi 2010 - 2025, Grand Design Reformasi Birokrasi adalah rancangan induk yang berisi arah dan kebijakan pelaksanaan reformasi birokrasi nasional untuk kurun waktu 2010-2025, pilot project awal pelaksanaan reformasi birokrasi yaitu Kementrian Keuangan, Mahkamah Agung, dan Badan Pemeriksa Keuangan, pelaksanaan reformasi birokrasi dalam rangka mewujudkan tata kelola pemerintahan yang baik melalui langkah strategis untuk membangun aparatur negara agar lebih berdaya dan berhasil guna dalam melaksanakan tugas umum pemerintahan dan pembangunan nasional dengan tiga sasaran utamanya, yaitu peningkatan kapasitas dan akuntabilitas organisasi, pemerintah yang bersih dan bebas Korupsi, Kolusi, dan Nepotisme (KKN), serta peningkatan pelayanan publik.

Grand Design Reformasi Birokrasi 2010 - 2025 mempunyai makna sebagai sebuah langkah perubahan besar dalam paradigma untuk mengelola pemerintahan Indonesia dalam menghadapi tantangan abad ke-21. Apabila berjalan dengan baik maka reformasi birokrasi akan mencapai tujuan yang diharapkan, seperti mengurangi dan akhirnya menghilangkan setiap penyalahgunaan kewenangan publik oleh pejabat di instansi yang bersangkutan; menjadikan negara yang memiliki most-improved bureaucracy; meningkatkan mutu pelayanan kepada masyarakat; meningkatkan mutu dalam perumusan dan pelaksanaan kebijakan/program instansipemerintahan; meningkatkan efisiensi (biaya dan waktu) dalam pelaksanaan semua tugas organisasi; menjadikan birokrasi Indonesia antisipatif, proaktif, dan efektif dalam menghadapi globalisasi dan dinamika perubahan lingkungan strategis (Peraturan Presiden Nomor 81 Tahun 2010).

Reformasi birokrasi sebagai the artificial inducement of administrative transformation against resistance, yang dapat dimaknai bahwa reformasi secara administrasi adalah keinginan atau dorongan yang didesign agar terjadi perubahan atau transformasi bidang administrasi (Faedlulloh et al., 2020). Reformasi birokrasi dimaknai sebagai proses perubahan (bukan output ataupun hasil), ditandai adanya perubahan yang dinamis, tidak status quo, bersifat mendasar, berupa tatanan birokrasi baru yang lebih baik dari kondisi sebelumnya (Sunarno, 2020). Kementerian Keuangan sebagai organisasi yang selalu berkomitmen untuk terus maju dan sempurna dalam melaksanakan tugas dan 
fungsinya, telah menetapkan nilai-nilai yang diharapkan menjadi pedoman bagi setiap pegawai. Nilainilai itu adalah Integritas, Profesionalisme, Sinergi, Pelayanan, dan Kesempurnaan. Nilai-nilai tersebut disusun tentu dengan harapan para pegawai di lingkungan Kementerian Keuangan dapat memahami dan mengimplementasikan nilai-nilai tersebut, sehingga seluruh pegawai dapat menjadi unsur yang mendorong kemajuan organisasi, Integritas dalam Kamus Besar Bahasa Indonesia berarti "mutu, sifat, atau keadaan yang menunjukkan kesatuan yg utuh sehingga memiliki potensi dan kemampuan yang memancarkan kewibawaan; kejujuran." Kesatuan dalam hal ini berarti adanya konsistensi antara apa yang kita katakan dengan apa yang kita perbuat. Konsistensi dan keteguhan yang tak tergoyahkan dalam menjunjung tinggi nilai-nilai luhur dan keyakinan (Wahyudi, 2017).

Integritas menurut nilai-nilai kemetrian keuangan adalah berpikir, berkata, berperilaku dan bertindak dengan baik dan benar serta memegang teguh kode etik dan prinsip-prinsip moral (Kementrian Keuangan Republik Indonesia). Berdasarkan kamus kompetensi perilaku KPK, yang dimaksud dengan integritas adalah bertindak secara konsisten antara apa yang dikatakan dengan tingkah lakunya sesuai nilai-nilai yang dianut (nilai-nilai dapat berasal dari nilai kode etik di tempat dia bekerja, nilai masyarakat atau nilai moral pribadi) (Korupsi, 2020). Integritas adalah merupakan sikap pribadi seseorang yang terwujud dalam sikap cara seorang pemimpin meliputi kejujuran, kredibilitas, ketulusan berbicara, mengarahkan dan bereaksi terhadap pengikutnya dalam konteks kepemimpinan (Dumilah Ayuningtyas dkk, 2018).

Integritas adalah karakter yang mendasari timbulnya pengakuan professional yang mencerminkan integritas berupa kualitas sebagai dasar kepercayaan publik dan patokan (benchmark) bagi anggota dalam menguji semua keputusan yang diambilnya (Sukmana \& Indarto, 2018). Integritas adalah konsistensi dalam berperilaku, selaras dengan nilai, norma dan/atau etika organisasi, dan jujur dalam hubungan dengan manajemen, rekan kerja, bawahan langsung, pemangku kepentingan, menciptakan budaya etika tinggi dan bertanggungjawab atas tindakan atau keputusan beserta risiko yang menyertainya (Suhascaryo, 2021). Zona Integritas (ZI) merupakan predikat yang diberikan kepada instansi pemerintah di mana pimpinan dan jajarannya mempunyai komitmen untuk mewujudkan WBK/WBBM melalui reformasi birokrasi, khususnya dalam hal pencegahan korupsi dan peningkatan kualitas pelayanan publik. Wilayah Bebas dari Korupsi (WBK) adalah predikat yang diberikan kepada suatu unit kerja yang memenuhi sebagian besar manajemen perubahan, penataan tata laksana, penataan sistem manajemen SDM, penguatan pengawasan, dan penguatan akuntabilitas kinerja. Wilayah Birokrasi Bersih dan Melayani (WBBM) adalah redikat yang diberikan kepada suatu unit kerja yang memenuhi sebagian besar manajemen perubahan, penataan tata laksana, penataan sistem manajemen SDM, penguatan pengawasan, penguatan akuntabilitas kinerja, dan penguatan kualitas pelayanan publik (Permen PAN-RB Nomor 52 Tahun 2014). Pembangunan zona integritas itu adalah suatu upaya yang dilakukan oleh suatu unit kerja dalam rangka mendapatkan predikat zona integritas sesuai ketentuan yang berlaku (Indarjono, 2021).

Human Capital Management (HCM) oleh Chatzkel merupakan pengkuran untuk pengelolaan dan pengembangan kemampuan manusia untuk mencapai tingkat yang secara signifikan menjadi yang lebih tinggi secara kinerjanya, memandang sumber daya manusia sebagai sumber kunci organisasi, dan hasil pengukuran ini akan menentukan arah strategi HCM. sehingga pengembangan measurement tools menjadi penting, menilai dampak dari praktek People Management dan kontribusinya diukur hingga garis batas terendah performa kinerjauntuk menciptakan nilai (creating value) tujuannya untuk mengarahkan dan mengakselerasi strategi bisnis dan tidak mengangap manusia sebagai biaya, memandang penting tingkat efektivitas pengelolaan kekayaan manusia dalam pencapaian organisasi (Mursid, 2017). Dalam rangka pembangunan Zona Integritas, langkah-langkah yang perlu dilakukan adalah : Menyelaraskan instrumen Zona Integritas dengan instrumen evaluasi Reformasi Birokrasi, serta penyederhanaan pada indikator proses seperti program Manajemen 
Perubahan, Penataan Tatalaksana, Penataan Manajemen SDM, Penguatan Akuntabilitas Kinerja, Penguatan Pengawasan, dan Peningkatan Kualitas Pelayanan Publik dan indikator hasil yang lebih fokus dan akurat yaitu menghasilkan sasaran pemerintahan yang bersih dan bebas KKN serta peningkatan kualitas pelayanan publik (Permen PAN-RB Nomor 52 Tahun 2014).

Integritas berdasarkan nilai nilai Kementrian Keuangan adalah berpikir, berkata, berperilaku dan bertindak dengan baik dan benar serta memegang teguh kode etik dan prinsip-prinsip moral yang menunjuk pada konsistensi antara tindakan dengan nilai dan prinsip (Wahyudi, 2017). Integritas adalah merupakan sikap pribadi seseorang yang terwujud dalam sikap cara seorang pemimpin meliputi kejujuran, kredibilitas, ketulusan berbicara, mengarahkan dan bereaksi terhadap pengikutnya dalam konteks kepemimpinan. Zona Integritas (ZI) merupakan predikat yang diberikan kepada instansi pemerintah di mana pimpinan dan jajarannya mempunyai komitmen untuk mewujudkan WBK/WBBM melalui reformasi birokrasi, khususnya dalam hal pencegahan korupsi dan peningkatan kualitas pelayanan publik (Peraturan Menteri Pendayagunaan Aparatur Negara dan Reformasi Birokrasi Republik Indonesia Nomor 52 Tahun 2014, n.d.). Menurut (Julia Hapsari, 2019) Konsep zona integritas sebenarnya berasal dari konsep island of integrity. Island of integrity atau pulau integritas biasa digunakan oleh pemerintah maupun NGO (Non Government Organization) untuk menunjukkan semangat dalam pemberantasan dan pencegahan tindak pidana korupsi.

Kantor Pengawasan dan Pelayanan Bea dan Cukai Tipe Madya Pabean Ngurah Rai atau disingkat KPPBC TMP Ngurah Rai sebagai instansi pemerintah di bawah Kementerian Keuangan, berpartisipasi dalam pembangunan zona integritas untuk menuju Wilayah Bebas Korupsi dan Wilayah Birokrasi Bebas Melayani dan telah mencanangkan program pembangunan Zona Integritas sesuai dengan peraturan Menteri Pendayagunaan Aparatur Negara dan Reformasi Birokrasi Nomor 52 Tahun 2014 jo Permen PAN-RB No 10 Tahun 2019 tentang Pedoman Pembangunan Zona Integritas Menuju Wilayah Bebas Korupsi dan Wilayah Birokrasi Bersih dan Melayani di Lingkungan Instansi Pemerintah.

\section{METODE PENELITIAN}

Penelitian ini merupakan jenis penelitian kulitatif deskriptif untuk memperoleh hasil penelitian dilakukan wawancara semi terstruktur kepada pihak-pihak yang berkaitan dengan penelitian. Wawancara mendalam dilakukan kepada pegawai yang terlibat dalam pembangunan zona integritas yaitu Bidang Manajemen Perubahan, Penataan Tatalaksana, Penataan Manajemen SDM, Penguatan Akuntabilitas Kinerja, Penguatan Pengawasan, dan Peningkatan Kualitas Pelayanan Publik. Teknik pengumpulan data menggunakan metode tringulasi yakni wawancara, observasi dan study dokumen. Lokasi penelitian ini berada di kantor Pengawasan dan Pelayanan Bea dan Cukai Madya Pabean Ngurah Rai.

Sampel metode kualitatif tidak menekankan pada jumlah atau keterwakilan, tetapi lebih kepada kualitas informasi, kredibilitas dan kekayaan informasi yang dimiliki oleh informan atau partisipan (J.R Raco, 2018). Menurut (Sugiyono, 2016) tidak menggunakan istilah populasi dalam penelitian kualitatif, namun menggunakan istilah Social Situation atau situasi sosial yang terdiri atas tiga elemen yaitu place (tempat), actor (pelaku), dan activity (aktifitas).

Pada penelitian ini, informan dilakukan secara purposive sampling yaitu personal yang terlibat secara langsung seperti Kepala kantor, para kepala seksi dan para pelaksanan dalam Proses pembangunan zona intgritas dibidang Manajemen Perubahan, Bidang Penataan Tatalaksana, Bidang penataan Sistem Manajemen SDM, Bidang Penguatan Pengawasan, Bidang Penguatan Akuntabilitas Kinerja dan Bidang Penguatan Kualitas Pelayanan Publik pada KPPBC TMP Ngurah Rai. 


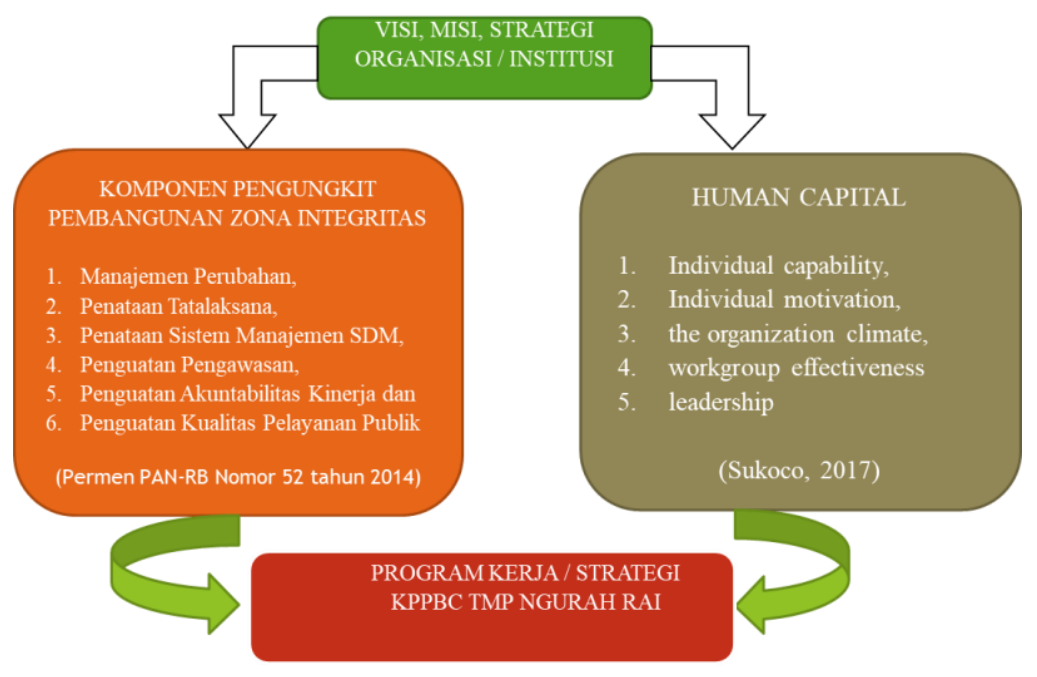

Gambar 1.

Kerangka konseptual Penelitian

Dalam penelitian ini akan mengulas tentang Strategi Manajemen Organisasi berdasarkan Permen PAN-RB Nomor 52 tahun 2014 jo Permen PAN-RB Nomor 10 Tahun 2019 tentang Pedoman Pembangunan Zona Integritas Menuju WBK dan WBBM di lingkungan Instansi Pemerintah, yang meliputi 6 area perubahan yaitu : Manajemen Perubahan, Penataan Tatalaksana, penataan Sistem Manajemen SDM, Penguatan Akuntabilitas Kinerja, Penguatan Pengawasan dan Penguatan Kualitas Pelayanan Publik. Sebagai upaya pemberdayaan Human Capital menggunakan pendekatan metode menurut Andrew Mayo (2000) dalam Ongkodihardjo (2008) dalam Sukoco, (2017) yang meliputi Individual capability, Individual motivation, the organization climate, workgroup effectiveness, dan leadership.

\section{HASIL DAN PEMBAHASAN}

Hasil analisis dari penelitian menunjukkan bahwa narasumber memiliki pemahaman yang mendalam tentang konsep dari pembangunan zona integritas pada KPPBC TMP Ngurah Rai. Program kerja dan Strategi Dalam Mewujudkan Pembangunan Zona Integritas yaitu perubahan pada organisasi pemerintahan dalam mewujudkan pembangunan zona integritas menuju Wilayah Bebas Korupsi (WBK) dan Wilyah Birokrasi Bersih Melayani (WBBM) menjadi suatu pekerjaan yang tidak mudah dan perlu extra effort untuk membangun integritas, transparansi dan akuntabilitas kinerja KPPBC TMP Ngurah Rai tidak hanya menjadi tugas dan fungsi dari seksi terkait saja (Kepatuhan Internal) namun menjadi tanggungjawab dari seluruh pegawai yang berada dibawahnya (Indarjono, 2021). perubahan budaya dan penguatan kualitas pelayanan namun dengan segala keterbatasan dan kekurangan diperlukan banyak masukan, arahan, kajian dan juga partisipasi dari seluruh pegawai untuk menyusun Program Kerja. Program kerja dalam rangka pembangunan zona intgritas sesuai dengan (Permen PAN-RB Nomor 52 Tahun 2014) yaitu komponen pengungkit yang meliputi 1. Manajemen Perubahan, 2. Penataan Tatalaksana, 3. Penataan Manajemen SDM, 4. Penguatan Akuntabilitas Kinerja, 5. Penguatan Pengawasan, dan 6. Peningkatan Kualitas Pelayanan Publik yang diharapkan dapat menghasilkan peningkatan pelayan publik dan pemerintah yang bersih dan bebas KKN. 
Manajemen perubahan bertujuan untuk mengubah secara sistematis dan konsisten mekanisme kerja, pola pikir (mind set), serta budaya kerja (culture set) individu pada unit kerja yang dibangun, menjadi lebih baik sesuai dengan tujuan dan sasaran pembangunan zona integritas (Peraturan Menteri Pendayagunaan Aparatur Negara dan Reformasi Birokrasi Republik Indonesia Nomor 52 Tahun 2014, n.d.) Program kerja dibidang Manajemen Perubahan pada KPPBC TMP Ngurah Rai meliputi : pembentukan tim kerja, penyusunan rencana kerja, Target Prioritas, Pimpinan Sebagai Role Model, Agen Perubahan, Budaya kerja dan pola pikir.

Menurut (Purnomo, 2020) dalam sesi wawancara penelitian tesis mengutarakan manajemen perubahan mempunyai tujuan merubah sitem dan cara kerja, cara berpikir dan budaya kerja pegawai pada unit kerja menjadi kearah yang lebih baik, berdaya saing sesuai dengan tujuan dan sasaran pembangunan zona integritas. Sesuai dengan apa yang dijelaskan Bapak Purnomo

“... jadi kalau orang itu mau berbuat baik itu dimulai kapan kegiatan itu dilakukan atau di canangkan, bicara masalah bea cukai, dulu memang banyak oknum-oknum yang membuat kesalahan tapi itu kan jaman dulu, misalnya kalau ditarik kebelakang 2 tahun yang lalu karena ada oknumoknum yang terlibat kesalahan-kesalahan masa lalu ya tidak perlu dipermasalahkan lagi, jadi pencanangan pembangunan zona integritas itu yang akan menjadi titik tolak kebaikan yang akan kita sampaikan pengguna jasa, ..."

Adapun tambahan dari Bapak Purnomo terkait rangka pembangunan zona integritas yakni 1). Pembentukan tim kerja. 2). Penyusunan rencana kerja 3). Target Prioritas. 4). Pimpinan sebagai role model. 5). Agen Perubahan. 6). Budaya Kerja dan Pola Pikir. 7). Keterlibatan Anggota. 8). Monitoring dan Evaluasi. Pada pembangunan zona integritas tentu memiliki hambatan dalam pembangunannya. Integritas yang tidak maksimal menjadi faktor pertama dalam hambatan ini.

Pembentukan tim kerja yakni Tim pembangunan Zona Integritas menuju WBK/WBBM pada KPPBC TMP Ngurah Rai telah dibentuk dengan Surat Keputusan Kepala dengan beberapa perubahan anggota tim karena mutasi pegawai dilingkungan Direktorat Jenderal Bea dan Cukai. 2). Penyusunan rencana kerja, KPPBC TMP Ngurah Rai telah memiliki rencana kerja pembangunan ZI menuju WBK/WBBM, salah satunya yaitu membuat kajian tentang proyek perubahan, pencanangan pembangunan zona intgritas dan penandatanganan dokumen pakta intgritas. 3). Target Prioritas, KPPBC TMP Ngurah Rai telah menetapkan dokumen rencana kerja pembangunan Zona Integritas menuju WBK/WBBM yang memuat target-target prioritas yang relevan dengan tujuan pembangunan WBK/ WBBM.

Pimpinan sebagai role model. Kepala KPPBC TMP Ngurah Rai telah memberikan teladan nyata bagi seluruh pegawai di KPPBC TMP Ngurah Rai, dibuktikan dengan : Penghargaan dari Kemen PAN-RB kepada Bapak Himawan Indarjono sebagai pelopor Perubahan Pembangunan Zona Iintgeritas pada KPPBC TMP Ngurah Rai, Laporan Absensi Kepala KPPBC TMP Ngurah Rai, Pakta Integritas yang ditandatangani Kepala Kantor dan seluruh unit dibawah jajarannya, Bukti Pengiriman SPT, LP2P (Alpha) Bukti Pengiriman e-LHKPN Kepala Kantor dan Dokumentasi Pencanganan Zona Integritas oleh Kepala KPPBC TMP Ngurah Rai (melalui beberapa media seperti pada bengurahrai.beacukai.go.id dan (www.instagram.com/beacukaingurahrai).

Agen Perubahan. Change Agent/Agen Perubahan pada KPPBC TMP Ngurah Rai pejabat dan pegawai terpilih yang menjadi pelopor perubahan dan sekaligus dapat menjadi contoh dan panutan dalam berperilaku yang mencerminkan integritas dan kinerja yang tinggi sebagai perwujudan nilai nilai Kementrian Keuangan (Indarjono, 2021). Agen perubahan pada KPPBC TMP Ngurah Rai telah ditetapkan sesuai dengan Surat Keputusan kepala kantor.

Budaya Kerja dan Pola Pikir. KPPBC TMP Ngurah Rai telah berupaya untuk membangun budaya kerja dan pola pikir melalui berbagai kegiatan, dibuktikan dengan : P2KP bimbingan mental dari Pak Endro Sudarmanto (Kanwil DJBC Bali, NTB, dan NTT) pada tanggal 21 Maret 2018, 
Pencanangan Zona Integritas, Pelaksanaan Apel Pagi Penegakan Disiplin terkait Hari Anti Korupsi, Pelaksanaan Pekan Disiplin Setiap Bulan, Pelaksanaan Sosialisasi Internal (P2KP) tentang pembangunan ZI menuju WBK dan WBBM di KPPBC Ngurah Rai pada tanggal 07 Desember 2017, kuesioner melalui google form untuk memperoleh masukan dari seluruh pejabat/pegawai KPPBC TMP Ngurah Rai mengenai kejadian-kejadian di lapangan, kendala dan hal-hal lain yang perlu diperbaiki. Adapun alamat google formnya http://bit.ly/SurveiWBBM, Pemaparan Materi terkait Gratifikasi dan Pelaporannya kepada Pegawai On Job Training dan pengguna jasa.

Keterlibatan Anggota. Proses pembangunan zona integritas di KPPBC TMP Ngurah Rai melibatkan seluruh elemen kantor berperan aktif mulai dari pejabat, pegawai, semuanya termasuk pegawai non pegawai negeri, setiap masing-masing elemen kantor berperan sesuai dengan tupoksinya masing-masing (Hartono, 2020), bukti keterlibatan pegawai yaitu Tanda Tangan Pakta Integritas yang ditandatangani oleh seluruh pegawai, Penandatanganan Kanvas yang berisikan komitmen KPPBC TMP Ngurah Rai dalam mewujudkan Zona Integritas menuju WBK/WBBM, rapat perkembangan Zona Integritas, pengawasan melekat bulanan setiap seksi yang setidak-tidaknya berisi materi intergitas, kode etik pegawai, dan ISO, kuesioner melalui google form untuk memperoleh masukan dari seluruh pejabat/pegawai KPPBC TMP Ngurah Rai mengenai kejadian-kejadian di lapangan, kendala dan hal-hal lain yang perlu diperbaiki, Diadakan lomba inovasi untuk seluruh pejabat dan pegawai, Diadakan penjaringan masukan dan pendapat dari seluruh pejabat dan pegawai mengenai pembangunan ZI/WBK/WBBM melalui link bit.ly/surveiNR2 mulai 8 November 2019, Menjadikan pencapaian pembangunan ZI menuju WBBM sebagai IKU Wajib.

Monitoring dan Evaluasi. Semua kegiatan pembangunan ZI tahun 2018 KPPBC Ngurah Rai telah dilaksanakan sesuai dengan rencana seperti Laporan Progress Perkembangan Pembangunan Zona Integritas KPPBC TMP Ngurah Rai, Laporan Evaluasi dan Monitoring Pembangunan ZI Menuju WBK/WBBM, Laporan Progress, Monitoring, dan Evaluasi Kegiatan Pembangunan ZI seluruh Subtim.

Penataan tatalaksana mempunyai tujuan untuk meningkatkan efisiensi dan efektivitas sistem, proses dan prosedur kerja yang jelas efektif, efisien, dan terukur pada Zona Integritas Menuju WBK/WBBM (Peraturan Menteri Pendayagunaan Aparatur Negara dan Reformasi Birokrasi Republik Indonesia Nomor 52 Tahun 2014). Bidang Penataan tatalaksana pada KPPBC TMP Ngurah Rai dalam mewujudkan pembangunan zona integritas memliki program kerja meliputi : 1). Monitoring Standard Operatinal Prosedur (SOP). 2). Peningkatan kuantitas dan Pendalaman terkait Audit. 3). Monitoring penggunaan IT. 4). Percepatan Janji Layanan. 5). Percepatan Janji Layanan. 6). Inovasi Oleh Pegawai. 7). Penerapan E-Office Dengan Pengembangan Samurai Versi 5.0. 8). Talent Mapping (Wisuda, 2020), dalam sesi wawancara Bapak Jalu Restu Wisuda selaku ketua bidang penataan tata laksana menjelaskan "...Tiap tahun dari unit kepatuhan internal melakukan survei kepuasan kepada masyarakat/pengguna jasa, dari survei itu kita jadikan masukan bagi kami untuk dilakukan perbaikan, seperti contoh dibagian tata laksana kira-kira ada tidak celah/ titik-titik yang masyarakat belum puas, karena ketika ada yang belum puas kita melakukan pendalaman/perbaikan disitu, perbaikan seperti apa yang ingin dirasakan pengguna jasa, kalau misal itu bisa dilakukan perbaikan, kita lakukan perbaikannya karena sebagaimana kita ketahui ada ISO 9001:2015 tentang pelayanan mutu sangat membantu karena kita berstandarisasi internasional, setiap tahun kita diaudit eskternal oleh lembaga penerbit ISO tersebut dan dari mereka pun kita mendapatkan masukan, bagaimana cara menetapkan PDK atau pedoman kerja.......".

Monitoring Standard Operatinal Prosedur (SOP). Seluruh SOP pada KPPBC TMP Ngurah Rai telah mengacu pada Peta Proses Bisnis DJBC nomor KEP-538/BC/2019, Keseluruhan SOP dapat diakses dengan mudah oleh semua pegawai melalui portal CEHRIS dan Ditambah dengan KPPBC TMP Ngurah Rai telah melakukan inovasi yang selaras dilakukan penyesuaian sesuai karakteristik 
KPPBC TMP Ngurah Rai dengan menerapkan standar mutu ISO 9001:2015 yang dibuktikan dengan Pedoman Kerja (PDK). Atas seluruh SOP utama yang telah disebutkan, KPPBC TMP Ngurah Rai telah melaksanakan monitoring terhadap masa berlaku dan penerapan atas SOP tersebut.

Peningkatan kuantitas dan Pendalaman terkait Audit. Telah diadakan pelatihan awareness berdasarkan SNI ISO 9001:2015 dan pelatihan Internal Audit, Telah dilakukan monitoring dan evaluasi SOP. Monitoring penggunaan IT. KPPBC TMP Ngurah Rai telah memiliki sistem pengukuran kinerja berbasis Teknologi Informasi berupa Sistem Aplikasi E-performance, penggunaan Sistem Aplikasi Mandiri BC Ngurah Rai (SAMURAI) untuk pengukuran kinerja, pelaksanaan dialog kinerja organisasi dan pelaporan capaian kinerja Di Lingkungan DJBC menggunakan mekanisme Elogbook pada Customs and Excise Human Resources Information System (CEHRIS), sistem operasionalisasi manajemen SDM yaitu HRIS (Human Resourses Information System, Laporan Gangguan Bea Cukai Ngurah Rai (LUNAR) dalam memberikan pelayanan kepada publik.

Percepatan Janji Layanan. Layanan prima berorientasi kepada pengguna jasa, janji layanan pada 35 SOP ditetapkan Bea Cukai Ngurah Rai lebih cepat dari standar Pusat, termasuk di dalamnya terdapat 12 layanan yang kembali dipercepat lagi di tahun 2020. Implementasi percepatan janji layanan sesuai dengan Keputusan Kepala Kantor. Inovasi Oleh Pegawai. KPPBC TMP Ngurah Rai Mengadakan acara kompetisi inovasi kepada seluruh pegawai dengan memberikan hadiah kepada 3 (Tiga) pemenang inovasi utama yang dapat diimplementasikan. Hal ini diakukan karena factor penunjang yang utama yang diidentifikasikan sebagai kekuatan KPPBC adalah adanya SDM yang berkualitas dan memiliki kompetensi yang tinggi Penerapan E-Office Dengan Pengembangan Samurai Versi 5.0. Aplikasi utama pendukung e-office yang disempurnakan 26 April 2019, mendukung akuntabilitas pengelolaan kinerja, penambahan menu database kompetensi pegawai, direktori peraturan dan dokumen ISO dan pemutakhiran pada aplikasi PIBK, CD Bayar, ATA Carnet, Aplikasi PPP Penetapan SOP oleh Bea Cukai Ngurah Rai dengan janji layanan penyelesaian lebih cepat.

Talent Mapping. Sesuai dengan Nota Dinas ND-354/WBC.13/KPP.MP.0119/2019 tanggal 23 September 2019 perihal lomba inovasi KPPBC TMP Ngurah Rai, terdapat salah satu inovasi “ Implementasi Talent Mapping " sebagai salah satu Pertimbangan dalam menerapkan mutasi internal pegawai yaitu penempatan pegawai dengan menggunakan aplikasi www.temubakat.com untuk seluruh pegawai. Dari hasil penelitian di bidang tata laksana di peroleh hasil pentingnya evaluasi dan monitoring atas semua kegiatan yang dilakukan agar sesuai standar operasional prosedure dan sesuai dengan hasil yang ditetapkan.

Penataan sistem manajemen Sumber Daya Manusia bertujuan untuk meningkatkan profesionalisme Sumber Daya Manusia pada Zona Integritas Menuju WBK/WBBM (Peraturan Menteri Pendayagunaan Aparatur Negara dan Reformasi Birokrasi Republik Indonesia Nomor 52 Tahun 2014). Manajemen strategi human capital dalam suatu organisasi menekankan pengertian bahwa manusia merupakan salah satu modal utama dalam menjalankan keberhasilan organisasi dengan nilai dan jumlah yang tidak terhingga, yang dapat dikelola dalam suatu proses dan pada akhirnya menghasilkan value-added bagi para stakeholders (Prasojo et al., 2017). Pegawai di KPPBC TMP Ngurah Rai di pandang sebagai human capital karena SDM adalah salah satu komponen penting dalam organisasi untuk mencapai tujuan, bagaimana kita mencari SDM yang handal kita harus mampu memetakan kebutuhan-kebutuhan SDM itu sendiri, baik teknis maupun non teknis, kalau teknis seperti diklat, kalau non teknis itu seperti kita tau mungkin rataan SDM dikantor sini kalau tidak salah 90\% nya generasi millenial dan generasi $\mathrm{z}$ dengan rata-rata usia yang didominasi usia di bawah 30 tahun, menjadikan Bea Cukai Ngurah Rai memiliki sumber daya manusia yang dinamis, enerjik, berdaya juang tinggi, kreatif dan pantang menyerah (Priono, 2020).

Berdasarkan data kepegawaian di Sub bagian umum KPPBC TMP Ngurah Rai memiliki pegawai dengan status Pegawai Negeri Sipil (PNS) pada tahun 2020 berjumlah sebanyak 281 pegawai. 
Menurut YiChing Chen dkk., 2012 dalam (Hutagalung \& Perdhana, 2016) faktor usia merupakan salah satu bentuk dari karakteristik demografi human capital dimana usia menjadi salah satu faktor yang memberikan pengaruh baik terhadap kinerja dan juga komitmen organisasional seorang karyawan dalam organisasi. Peningkatan kompetensi pegawai adalah kegiatan pelatihan yang bertujuan untuk meningkatkan pengetahuan dan keterampilan pegawai sehingga mampu meningkatkan kualitas kinerja organisasi. Pemetaan jabatan dan analisa beban kerja. kebutuhan pegawai yang disusun oleh unit kerja mengacu kepada peta jabatan dan hasil analisis beban kerja untuk masing-masing jabatan dengan Laporan Analisis Beban Kerja (ABK) setiap tahun.

Penempatan pegawai sesuai kebutuhan organisasi. penempatan pegawai hasil dari rekrutmen murni yang mengacu kepada kebutuhan organisasi dimana penempatan pegawai telah disusun per jabatan dan telah dilakukan monitoring dan dan evaluasi terhadap penempatan pegawai untuk memenuhi kebutuhan jabatan dalam organisasi untuk memberikan perbaikan terhadap kinerja unit kerja. KPPBC TMP Ngurah Rai telah melakukan Training Need Analysis untuk mengembangkan kompetensi pegawai pada KPPBC TMP Ngurah Rai, dibuktikan dengan :Dokumen Identifikasi Kebutuhan Diklat (IKD), melakukan analisa kebutuhan untuk kegiatan pembelajaran yang dituangkan dalam bentuk Dokumen Analisis Kebutuhan Pembelajaran (AKP).

Pengembangan Kompetensi Pegawai. KPPBC TMP Ngurah Rai melakukan rencana pengembangan kompetensi pegawai telah mempertimbangkan hasil pengelolaan kinerja pegawai yang dibuktikan dengan Keputusan Penetapan Kinerja Pegawai Usulan Pengembangan Kompetensi dan Hasil Penilaian Atasan dan Pemetaan Pegawai. Persentase kesenjangan kompetensi pegawai yang ada dengan standar kompetensi yang ditetapkan untuk masing-masing jabatan dari 22 orang pejabat yang telah mengikuti Assessment Center, sebanyak 20 orang (90\%) memiliki Job Person Match di atas 75\% (kesenjangan kompetensi kurang dari 25\%), sehingga sebanyak 10\% memiliki kesenjangan kompetensi di bawah 75\%. pegawai pada unit kerja telah memperoleh kesempatan/hak untuk mengikuti diklat maupun pengembangan kompetensi lainnya.

Pengukuran Kinerja Individu. KPPBC TMP Ngurah Rai telah melakukan penetapan kinerja individu yang terkait dengan kinerja organisasi kepada seluruh pegawai, dibuktikan dengan dokumen berupa Kontrak Kinerja Pegawai, pengukuran kinerja individu dilakukan secara periodik. Dalam rangka mendukung kampanye eco office, KPPBC TMP Ngurah Rai mengembangkan aplikasi mandiri (SAMURAI) yang berisi Logbook sehingga pengisian logbook menggunakan aplikasi dan mengurangi penggunaan kertas, hasil penilaian kinerja individu telah dijadikan dasar untuk pemberian reward (pengembangan karir individu, penghargaan dll).

Penegakan Kode Etik dan Disiplin Pegawai. KPPBC TMP Ngurah Rai telah mengimplementasikan seluruh aturan disiplin/kode etik/kode perilaku sesuai dengan aturan yang ditetapkan organisasi seperti Laporan Bulanan Ketertiban Pegawai, Bukti Tanda Tangan Pakta Integritas yang ditandatangani oleh seluruh pegawai KPPBC TMP Ngurah Rai, Laporan Bulanan atas pelanggaran Jam Kerja, pengadaan banner terkait penegakan aturan disiplin, kode etik, dan tolak gratifikasi, Bukti Penyampaian SPT Pajak Tahunan, LHK dan LP2P melalui Aplikasi ALPHA terhadap seluruh pejabat dan pegawai KPPBC TMP Ngurah Rai, serta LHKPN bagi pejabat yang wajib melaporkan LHKPN, Pelaksanaan Sidak, pemasangan CCTV di setiap unit kerja.

Akuntabilitas kinerja adalah suatu bentuk perwujudan kewajiban instansi pemerintah untuk mempertanggungjawabkan keberhasilan/kegagalan pelaksanaan program dan kegiatan dalam mencapai misi dan tujuan organisasi, program tersebut bertujuan untuk meningkatkan kapasitas dan akuntabilitas kinerja instansi pemerintah (Permen PAN-RB Nomor 52 Tahun 2014). Bidang penguatan akuntabilitas kinerja dalam mewujudkan pembangunan zoan integritas pada KPPBC TMP Ngurah Rai mempunya program kerja/stategi yang menggambarkan upaya unit kerja dalam meningkatkan efisiensi dan efektivitas penggunaan sumber daya, keterlibatan pimpinan dalam penyusunan perencanaan dan 
penetapan kinerja dan pengelolaan akuntabbilitas kinerja dengan melibatkan seluruh pejabat dan pegawai yang meliputi : Kontrak kinerja, monitoring capaian kinerja, laporan capaian kinerja, laporan kinerja, penignkatan sumber daya manusia yang kompeten, Peningkatan pemahaman pegawai terkait akuntabilitas kinerja, Efisiensi dan Efektifitas penggunaan sumber daya (Purwono, 2020).

Keterlibatan Pimpinan dalam Penyusuna Kontrak Kinerja. Dalam sesi wawancara dengan Bapak Herry Purwono anggota tim Bidang Penguatan akuntabilitas kinerja menjelaskan "..ada 2 komponen utama, yang pertama adalah keterlibatan pimpinan, apakah pimpinan terlibat langsung dalam pembentukan perencanaan dalam hal akuntabilitas yang berkaitan dengan kinerja, yang kedua adalah masalah pengelolaan kinerja...". KPPBC TMP Ngurah Rai telah memiliki seluruh dokumen perencanaan (Rencana Strategis dan Penetapan Kinerja), dimana seluruh pimpinan unit kerja (Kepala KPPBC TMP Ngurah Rai dan para kepala seksi) telah terlibat secara langsung pada saat penyusunan perencanaan, penyusunan rencana kinerja tahunan yang tertuang dalam perjanjian Kontrak Kinerja setiap tahunnya, penandatanganan KK dan pakta integritas, serta terlibat dalam pembangunan ZI menuju WBK/WBBM. Seluruh Pimpinan Unit (Kepala KPPBC TMP Ngurah Rai dan Seluruh Pejabat Eselon IV) telah terlibat secara langsung pada saat penyusunan dan penetapan IKU, pembuatan dan/ penyusunan kontrak kinerja, penandatanganan dan penetapan KK/IKU.

Tabel 1.

Hambatan dan Solusi selama Proses Penguatan Akuntabilitas

\begin{tabular}{|c|c|c|}
\hline No & Hambatan / kendala & Solusi \\
\hline 1 & $\begin{array}{l}\text { Kurang peran aktifnya pengguna jasa dalam } \\
\text { menyampaikan pengaduan atas tindakan oknum } \\
\text { pegawai }\end{array}$ & $\begin{array}{l}\text { mengimplementasikan Kebijakan Pengaduan } \\
\text { Masyarakat dan Whistleblowing system (WBS) } \\
\text { menjamin kerahasian pelapor. }\end{array}$ \\
\hline 2 & $\begin{array}{l}\text { Masih terjadinya konflik antara pengguna jasa } \\
\text { dengan pegawai yang sulit di buktikan }\end{array}$ & $\begin{array}{l}\text { pemasangan CCTV pada tempat-tempat yang } \\
\text { rawan terjadi Konflik dan menimbulkan pengaduan } \\
\text { seperti Meja Tempat Pemeriksaan Barang } \\
\text { Penumpang ( Meja Tumbang) }\end{array}$ \\
\hline 3 & Kurang kesadaran terkait gratifikasi & $\begin{array}{l}\text { KPPBC TMP Ngurah Rai telah } \\
\text { mengimplementasikan pengendalian gratifikasi } \\
\text { sesuai dengan yang ditetapkan organisasi dan juga } \\
\text { membuat inovasi terkait pengendalian gratifikasi } \\
\text { yang sesuai dengan karakteristik unit kerja dan } \\
\text { telah melakukan Public Campaign secara berkala } \\
\text { tentang Pengendalian Gratifikasi secara Berkala, } \\
\text { pembetukan SATGAS anti Gratifikasi, } \\
\text { pemeriksaan mendadak, Sosialisasi, internalisasi, } \\
\text { dan Program Pembinaan Keterampilan Pegawai } \\
\text { (P2KP) tentang Pencegahan dan Penanganan } \\
\text { Gratifikasi }\end{array}$ \\
\hline
\end{tabular}

Sumber: KPPBC TMP Ngurah Rai, 2021

Monitoring capaian kinerja. Seluruh Pimpinan Unit (Kepala KPPBC TMP Ngurah Rai dan Seluruh Pejabat Eselon IV) melakukan pemantauan pencapaian kinerja unit kerja secara berkala dengan melaksanakan Rapat Capaian IKU Kemenkeu-Three setiap bulan melalui dialog kinerja organisasi yang dipimpin langsung oleh Kepala Kantor. Dalam pelaksanaan Dialog Kinerja Organisasi dibahas masalah pencapaian kinerja dan isu-isu penting lainnya sehubungan dengan pelaksanaan tugas dan fungsi DJBC pada KPPBC TMP Ngurah Rai. Peserta DKO meliputi pejabat eselon IV, eselon V dan pelaksana di lingkungan KPPBC TMP Ngurah Rai. 
Laporan capaian kinerja. Pelaporan kinerja pada KPPBC TMP Ngurah Rai telah memberikan informasi tentang kinerja Sehingga dapat disimpulkan terdapat 14 IKU Kepala KPPBC TMP Ngurah Rai yang berstatus hijau. Laporan kinerja. KPPBC TMP Ngurah Rai telah menyusun Laporan Kinerja tepat waktu hal ini dapat dibuktikan dengan penyampaian LAKIN KPPBC TMP Ngurah Rai. Peningkatan sumber daya manusia yang kompeten. Pengelolaan Akuntanbilitas Kinerja pada KPPBC TMP Ngurah Rai, telah dilaksanakan oleh SDM yang berkompeten Seluruh pegawai yang sudah memiliki kompetensi sebagai pengelola kinerja ditunjuk untuk membantu melakukan pengelolaan kinerja pada KPPBC TMP Ngurah Rai dan telah memiliki/mengikuti pelatihan/diklat/internalisasi terkait akuntanbilitas/pengelolaan kinerja.

Peningkatan pemahaman pegawai terkait akuntabilitas kinerja. Sebagai upaya KPPBC TMP Ngurah Rai meningkatkan SDM terkait Pengelolaan Akuntanbilitas Kinerja pada pegawai yang mengelola akuntanbilitas kinerja di KPPBC TMP Ngurah Rai, dalam keterbasan anggaran, waktu, dan kuota pelatihan pengelolaan kinerja, diselenggarakan internalisasi pengelolaan kinerja secara mandiri dan penugasan kepada seluruh anggota seksi KI untuk mengikuti 8 microelearning terkait pengelolaan kinerja

Efisiensi dan Efektifitas penggunaan sumber daya. Penyusunan IKU bagi seluruh pejabat dan pegawai pada KPPBC TMP Ngurah Rai, mulai dari pimpinan hingga seluruh bawahan harus memenuhi konsep SMART-C. Tidak hanya SMART saja tetapi ada unsur tambahan C-nya, Penjelasan SMART-C Indikator Kinerja KPPBC TMP Ngurah Rai telah SMART-C karena harus memenuhi kriteria sebagaimana terdapat pada Keputusan Menteri Keuangan Nomor 467/KMK.01/2014 tentang Pengelolaan Kinerja di Lingkungan Kementerian Keuangan yakni : 1). Spesifik (Mampu menyatakan sesuatu secara definitif). 2). Measurable (Dapat diukur dengan jelas dan jelas cara pengukurannya). 3). Agreeable (Disepakati oleh pemilik IKU dan atasannya). 4). Realistic (Ukuran yang dapat dicapai dengan target menantang). 5). Time-Bounded (Memiliki batas waktu pencapaian). 6). Continous Improvement (selalu ada perbaikan terus menerus).

Penguatan pengawasan bertujuan untuk meningkatkan penyelenggaraan pemerintahan yang bersih dan bebas KKN pada masing-masing instansi pemerintah meningkatnya kepatuhan, efektifitas, menurunnya tingkat penyalahgunaan wewenang pada masing- masing instansi pemerintah (Peraturan Menteri Pendayagunaan Aparatur Negara dan Reformasi Birokrasi Republik Indonesia Nomor 52 Tahun 2014). Bidang penguatan pengawasan dalam mewujudkan pembangunan zona integritas di KPPBC TMP Ngurah Rai mempunyai program kerja sebagai berikut Penanganan Pengaduan Masyarakat, Peningkatan Integritras Anti Gratifikasi (SPIP), Menekan Jumlah Pengaduan Masyarakat (Wistle blower system. Benturan kepentingan) (Sudana, 2021).

Penanganan Pengaduan Masyarakat. KPPBC TMP Ngurah Rai telah mengimplementasikan pengendalian gratifikasi sesuai dengan yang ditetapkan organisasi dan juga membuat inovasi terkait pengendalian gratifikasi yang sesuai dengan karakteristik unit kerja, Pembentukan SATGAS Pengawasan dan Monitoring Gratifikasi, Penerapan Inovasi mekanisme Penerimaan Saran secara tertutup/Closed Feedback, Pembentukan Satuan Tugas Pengawasan dan Monitoring Gratifikasi dan Tim Kami Sadar Gratifikasi (KASASI).

Peningkatan Integritras Anti Gratifikasi. KPPBC TMP Ngurah Rai telah membangun seluruh lingkungan pengendalian (8 aspek) sesuai dengan PP 60 tahun 2008 tentang SPIP dan KMK940/KMK.09/2017 tentang Kerangka Kerja Penerapan Pengendalian Intern dan Pedoman Pemantauan Pengendalian Intern Di Lingkungan Kementerian Keuangan dan juga membuat inovasi terkait lingkungan pengendalian yang sesuai dengan karakteristik unit kerja yaitu : Laporan PPU ( Pengujian Pengendalian Utama ), Penyampaian Rencana Pemantauan Tahunan, Laporan Pemantauan Manajemen Resiko, Penegakan integritas dan nilai etika, Komitmen terhadap kompetensi , Inovasi Pemasangan dan Pemantauan CCTV yang dapat merekam video dan suara, Seluruh Seksi yang 
Memberikan layanan ke Pengguna Jasa, Seluruh Pelaksana, Pejabat Fungsional,dan Tim UPG KPPBC TMP Ngurah Rai diwajibkan mengikuti e-Learning Bimbingan Teknis Program Pengendalian Gratifikasi (PPG, Laporan FRS ( Fraud Risk Scenario).

Menekan Jumlah Pengaduan Masyarakat. KPPBC TMP Ngurah Rai telah mengimplementasikan Kebijakan Pengaduan Masyarakat dan Whistleblowing system (WBS), Mengimplementasikan kebijakan pengaduan masyarakat melalui Saluran Mandiri Pengaduan Masyarakat melalui Aplikasi SIPUMA, Email, telepon Pengaduan, kotak pengaduan, Akun media sosial KPPBC TMP Ngurah Rai, Inovasi dalam hal Penanganan Pengaduan Masyarakat.

Peningkatan kualitas pelayanan publik adalah suatu upaya meningkatkan kualitas dan inovasi pelayanan publik pada masing-masing instansi pemerintah secara berkala sesuai kebutuhan dan harapan masyarakat. Disamping itu, peningkatan kualitas pelayanan publik dilakukan untuk membangun kepercayaan masyarakat terhadap penyelenggara pelayanan publik dalam rangka peningkatan kesejahteraan masyarakat dengan menjadikan keluhan masyarakat sebagai sarana untuk melakukan perbaikan pelayanan publik (Permen PAN-RB Nomor 52 Tahun 2014). Program kerja terkait bidang penguatan kualitas pelayanan publik dalam mewujudkan pembangunan zona integritas pada KPPBC TMP Ngurah Rai yaitu Peningkatan sarana layanan terpadu, Memperluas akses informasi, Inovasi Pelayanan, Maklumat standar pelayanan dan Sosialisasi budaya pelayanan prima, akan tetapi yang menjadi hambatan dalam menjalan kan program ini adalah pelayanan prima (Nuaba, 2020).Peningkatan sarana layanan terpadu. KPPBC TMP Ngurah Rai telah memiliki kebijakan standar pelayanan yang ditetapkan organisasi yaitu Janji Layanan, Standar Pelayanan, Inovasi dimana Kebijakan standar pelayanan dan janji pelayanan yang telah bersertifikasi ISO 9001:2015 tentang pengendalian mutu dan kualitas atas pelayanan kepada pengguna jasa, percepatan janji layanan dari segi waktu atau lamanya standar pelayanan.

Memperluas akses informasi. Informasi tentang Pelayanan pada KPPBC TMP Ngurah Rai dapat diakses melalui berbagai media Melalui website bengurahrai.beacukai.go.id, Melaui Loket Layanan Informasi dan Kemudahan Layanan Informasi dan Izin Kebeacukaian (KLInIK), Melaui saluran telepon di (0361) 9351035 dan whatsaap di 081139935004 . Melalui layanan surat elektronik / email di kppbc.ngurahrai@customs.go.id dan ngurahraicustoms@gmail.com, Melaui saluran media sosial ( Facebook, Instagram, Youtube, Twitter), Melalui kegiatan customs goes to campus, Melalui media massa seperti Radio (HardRock, Menara, Urban dan Bali United radio) dan Melalui kegiatan Press Conference, Melalui Grup Whatsapp antara Pejabat dan Pegawai beserta Pengguna Jasa/Layanan di KPPBC TMP Ngurah Rai, Melalui kegiatan Customs Visit Customer, Melalui kegiatan kelas kepabeanan, Melalui layanan Nawala / newslatter, Melalui kegiatan Digital marketing campaign, Melalui siaran radio, Papan pengumuman di ruang layanan.

Inovasi Pelayanan. KPPBC TMP Ngurah Rai telah memiliki inovasi pelayanan yang berbeda dengan unit kerja lain dan mendekatkan pelayanan dengan masyarakat serta telah direplikasi seperti sistem Aplikasi Mandiri BC Ngurah Rai (SAMURAI), AplikasiSANTAI (Sistem Aplikasi Pengawasan \& Targeting Ngurah Rai), SITAMEC (Sistem Aplikasi targeting Meja CD), Pelayanan Pembayaran Bea Masuk dan PDRI atas barang impor yang dibawa penumpang, awak sarana pengangkut, dengan menggunakan Electronic Data Capture-EDC), Kemudahan Layanan Informasi dan Izin Kebeacukaian (KLInIK), Laporan Gangguan BeaCukai NgurahRai (LUNAR), pelakasaaan kelas kepabeanan, aplikasi Amburaga, Aplikasi Smart Asset, Aplikasi Adhe Rai ( Presensi Online ), ECD (Electronic - Customs Declaration).

Maklumat standar pelayanan. KPPBC TMP Ngurah Rai telah memaklumatkan seluruh standar pelayanan sesuai dengan yang ditetapkan organisasi Maklumat Standar Pelayanan adalah dengan membuat dalam 3 bahasa yaitu bahasa indonesia, bahasa inggris dan bahasa daerah bali. Ini 
sesuai dengan karateristik wilayah pengawasan dan pelayanan KPPBC TMP Ngurah Rai yaitu bandara internasional dan berolasi di provinsi Bali.

Sosialisasi budaya pelayanan prima.KPPBC TMP Ngurah Rai telah melakukan sosialisasi/pelatihan dalam upaya penerapan budaya pelayanan prima pada seluruh pegawai yang memberikan pelayanan : Pelaksanaan Program Pembinaan Keterampilan Pegawai (P2KP), Pelaksanaan Ceramah Motivasi tentang Peningkatan Motivasi Kinerja dalam Mendukung Bea Cukai Makin Baik, Pelaksanaan Pelatihan Bahasa Mandarin untuk meningkatkan kompetensi dan menunjang pelaksanaan tugas pegawai, Pelaksanaan pelatihan Service Level Agreement (SLA) bersamaan dengan pelaksanaan pelatihan operator dan Maintenance Mesin X-Ray, Pelaksanaan Pelatihan dan Pembinaan Mental Pegawai, Pelaksanaan Internalisasi atas peraturan dan layanan barang kiriman.

Program kerja dalam mewujudkan pembangunan zona integritas dalam meraih predikat Wilayah Bebas Korupsi (WBK) dan Predikat Wilayah Birokrasi Bersih Melayani (WBBM) disusun berdasarkan kajian akademis yang disusun oleh Ketua Subtim I Manajemen Perubahan sebagai panduan dalam melakukan perbaikan dalam rangka pembangunan Zona Integritas, sehingga proses perbaikan lebih terarah dan terpetakan dengan jelas, sehingga Rencana Kerja disusun benar-benar sesuai karakteristik Bea Cukai Ngurah Rai dengan melakukan kegiatan-kegiatan yang memaksimalkan factor-faktor pendorong (keunggulan) dan meminimalisasi faktor-faktor penghambat sehingga arah perubahan budaya semakin optimal. Perubahan tata kelola kantor meliputi penyederhanaan SOP mandiri Bea Cukai Ngurah Rai dalam bentuk Pedoman Kerja sesuai standar ISO 9001:2015, Pemberian percepatan janji layanan, Penerapan hasil inovasi pegawai, perubahan tat kelola kantor atas hasil dari pembangunan zona integritas, Pengelolaan kinerja yang paperless dan Komitmen Pimpinan sebagai Role Model. Perubahan Pendekatan Pengawasan. Penerapan inovasi kedalam sistem pengawasan seperti penerapan aplikasi E-CD, SITAMEC dan SANTAI ini merupakan langkah continue atas inovasi di bidang pengawasan dimana Inovasi ini mendukung pelayanan prima dan meningkatkan kenyamanan penumpang yang datang ke Indonesia melalui Bandara Internasional I Gusti Ngurah Rai.

Pemerintah Yang Bersih Dan Bebas KKN meliputi Predikat Wilayah Bebas Korupsi dan Predikat Wilayah Birokrasi Bersih Melayani demi pembangunan zona integritas. Zona Integritas adalah predikat yang diberikan kepada instansi pemerintah yang pimpinan dan jajarannya mempunyai komitmen untuk mewujudkan WBK/WBBM melalui reformasi birokrasi, khususnya dalam hal pencegahan korupsi yaitu sebagai berikut : Predikat Wilayah Bebas Korupsi dan Predikat Wilayah Birokrasi Bersih Melayani. Predikat Wilayah Bebas Korupsi. KPPBC TMP Ngurah Rai telah mendapatkan predikat Wilayah Bebas dari Korupsi pada tahun 2018 dari Kementerian Pendayagunaan Aparatur Negara dan Reformasi Birokrasi, sesuai Surat dari Sekretariat Direktorat Jenderal Bea dan Cukai Nomor S-2164/BC.01/2018 Tanggal 13 Juli 2018 tentang penyampaian hasil penilaian WBK/WBBMtingkat Kementrian Keuangan Tahun 2018

Tabel 2 .

Penilaian WBK Tahun 2018

\begin{tabular}{lllll}
\hline No & Komponen & Tim Kementerian & Tim Kemenpan & WBK/WBBM \\
\hline 1 & Pengungkit & 52.07 & 41.14 & $43.5 / 53.5$ \\
2 & Hasil & 36.87 & 36.44 & $31.5 / 31.5$ \\
& Total & 88.94 & 77.58 & $75 / 85$ \\
\hline
\end{tabular}

Sumber: WBK, 2018

Tolak ukur Keberhasilan dalam Pembangunan Zona Integritas dilihat dari hasil penilaian tingkat Kementeriaan Keuangan didapati nilai yang tinggi untuk komponen pengungkit dan juga 
komponen hasil (Skor 88.94) . Namun untuk tingkat nasional nilai yang diberikan oleh Tim Kemenpan dan RB sangat tipis diatas ambang batas nilai minimal untuk memperoleh WBK. (77.58). Pada tahun 2019 setelah mendapat predikat WBK di tahun 2018 KPPBC TMP Ngurah Rai pernah mengajukan penilaian WBBM tetapi gagal karena sebagai konsekuensi adanya inovasi-inovasi yang sebelumnya diakui di tingkat kementerian keuangan namun di penilaian tingkat nasional tidak dianggap sebagai inovasi jika tidak dikembangkan sendiri oleh KPPBC secara mandiri. Inovasi yang merupakan hasil penyusunan oleh Kantor Pusat DJBC tidak dihitung sebagai inovasi karena KantorKantor DJBC lainnya juga melakukan hal yang sama.Dalam proses menuju WBBM juga terdapat batasan-batasan bahwa inovasi yang sebelumnya telah dilakukan pada saat pencapaian WBK tidak boleh lagi untuk digunakan sebagai inovasi pada saat proses penilaian WBBM.

Tabel 3.

Penilaian WBBM

\begin{tabular}{lll}
\hline Syarat & WBK & WBBM \\
\hline Nilai total & 75 & 85 \\
Nilai Minimal Pengungkit & 40 & 48 \\
Bobot nilai minimal per area pengungkit & $60 \%$ & $75 \%$ \\
Nilai Komponen hasil "Terwujudnya Pemerintahan yang Bersih dan Bebas & & 18.50 \\
KKN" minimal & 18.50 & 13.50 \\
& 13.5 & $($ survey \\
Nilai Sub komponen "Survei Persepsi Anti Korupsi" minimal & $($ survey & $3.60)$ \\
Nilai Sub komponen "Persentasi TLHP" minimal & $3.60)$ & 5.0 \\
& 5.00 & 18 (survey \\
Nilai Komponen hasil "Terwujudnya Peningkatan Kualitas Pelayanan Publik & 16 (surve & $3.60)$ \\
Kepada Masyarakat" minimal & $3.20)$ & 2020 \\
BC Ngurah Rai Meraih di tahun & 2018 & \\
\hline
\end{tabular}

Sumber: Penilaian WBBM, 2020

Berdasarkan Keputusan Menteri Pendayagunaan Aparatur Negara dan Reformasi Birokrasi Indonesia Nomor 934 Tahun 2020 tentang Unit Kerja Berpredikat Menuju Wilayah Bebas dari Korupsi (WBK) dan Wilayah Birokrasi Bersih dan Melayani (WBBM), KPPBC TMP Ngurah Rai telah berhasil memperoleh predikat WBBM. Penilaian WBBM berdasarkan dari Pengukuran IKU pada penjumlahan nilai komponen pengungkit (60\%) dan nilai komponen hasil (40\%), dan apabila satuan kerja tersebut mendapatkan predikat WBBM, maka realisasi IKU-nya akan ditambahkan 20\% dari Nilai Evaluasi Reformasi Birokrasi. Realisasi IKU ini adalah sebesar 112,76\% dari target 85\% yang ditetapkan. Capaian IKU ini adalah Diantara hal yang mendukung tercapainya IKU ini adalah berhasilnya KPPBC TMP Ngurah Rai meraih predikat Wilayah Birokrasi Bersih dan Melayani (WBBM) tahun 2020.

Predikat Wilayah Birokrasi Bersih Melayani (WBBM). Berdasarkan Keputusan Menteri Pendayagunaan Aparatur Negara dan Reformasi Birokrasi Indonesia Nomor 934 Tahun 2020 KPPBC TMP Ngurah Rai telah berhasil memperoleh predikat WBBM. Penilaian Pembangunan ZI tidak hanya didasarkan atas pencapaian komponen pengungkit dan komponen hasil tetapi juga nuansa dan keadaan yang ada di lapangan baik di kantor maupun di hangar pelayanan. Oleh karena itu dibutuhkan komitmen pimpinan dan seluruh jajaran KPPBC TMP Ngurah Rai mulai dari PPNPN, Pelaksana, sampai ke level Pejabat untuk bersama-sama membangun Zona Integritas dan menjaganya. Kendala 
ini telah dilakukan mitigasi melalui upaya persuasive seperti rapat pengawasan melekat tiap seksi, Acara Townhall yang dipimpin langsung oleh Kepala Kantor, sampai penerapan inovasi integritas yang memperketat pengawasan terhadap penyimpangan integritas. Hasil dari mitigasi tersebut dapat dibuktikan keberhasilannya melalui Survei integritas yang dilaksanakan pada tahun 2020 kepada pengguna jasa KPPBC TMP Ngurah Rai atas proses pelayanan selama Semester I yang hasilnya menunjukkan bahwa tidak terdapat petugas yang meminta imbalan (uang) dalam memberikan pelayanan.

\section{SIMPULAN DAN SARAN}

Unit kerja berpredikat WBK/WBBM merupakan outcome dari upaya pencegahan korupsi yang dilaksanakan secara konkrit di dalam lingkup Zona Integritas. Pengembangan WBK/WBBM secara bertahap sejalan dengan konsep Zona Integritas. Diharapkan, upaya ini akan menjadi bagian dari upaya yang dapat meningkatkan nilai kepuasan persepsi birokrasi di Indonesia. Untuk itu diperlukan upaya dan pendekatan yang proaktif dalam rangka memperlihatkan kepada dunia internasional/global, bahwa upaya pencegahan korupsi di Indonesia dilakukan secara kontinyu dan komprehensif. KPPBC TMP Ngurah Rai telah berhasil mengimplemnetasikan Peraturan Menteri Pendayagunaan Aparatur Negara dan Reformasi Birokrasi Nomor 52 Tahun 2014 dengan menyandang predikat Wilayah Bebas Korupsi (WBK) Tahun 2018 dan Wilayah Birokrasi Bersih Melayani (WBBM) Tahun 2020 dan berhasil melakukan Reformasi Birokrasi di Pemerintahan. Pembangunan zona integritas mempunyai dampak yang sangat positif bagi suatu organisasi meskipun pencapaian tidak mudah dan penuh pengorbanan, dampak yang dirasakan disamping predikat WBK dan WBBM yaitu dampak penataan organisasi, tata kelola kantor, pimpinan sebagai role model, inovasi dan pencapaian indeks kepuasan pengguna jasa. Dan untuk mempertahankan capaian keberhasilan tersebut disarankan untuk tetap mempertahankan / meningkatkatkan komitmen intgritas bagi seluruh pegawai, meningkatkan inovasi pelayanan dan komitmen pimpinan sebagai role model dalam menjalankan pengawasan melekat.

\section{REFERENSI}

Dumilah Ayuningtyas dkk. (2018). Integritas Kepemimpinan Antikorupsi di Sektor Kesehatan. Integritas, 4(1), 28. https://doi.org/10.32697/integritas.v4i1.157

Dwiyanto, A. (2017). Mewujudkan Good Governance melalui pelayanan Publik. Gadjah Mada University Press. https://books.google.co.id/books?hl=id\&lr=\&id=fV0XEAAAQBAJ\&oi=fnd\&pg=PA1\&dq=good+governa nce+birokrasi

Faedlulloh, D., Maarif, S., Meutia, I. F., \& Yulianti, D. (2020). Indonesia Bureaucracy and Industrial Revolution 4 . 0 : Preventing the Myth of Smart Asn in Indonesia' S Bureaucratic Reform Agenda. 16(3), 313-336.

Fatkhuri, F. (2018). Korupsi dalam Birokrasi dan Strategi Pencegahannya. Jurnal Ilmiah Manajemen Publik Dan Kebijakan Sosial, 1(2), 65-76. https://doi.org/10.25139/jmnegara.v1i2.784

Hartono, T. (2020). Wawancara penelitian tesis dengan Kepala Seksi PKC II KPPBC TMP Ngurah Rai.

Hutagalung, S., \& Perdhana, M. S. (2016). PENGARUH KARAKTERISTIK DEMOGRAFIS (USIA, GENDER,PENDIDIKAN), MASA KERJA DAN KEPUASAN GAJI TERHADAP KOMITMEN AFEKTIF) (Studi Pada Tenaga Paramedik Non-PNS RSUD Kota Semarang). Jurnal Studi Manajemen Organisasi, 13(2), 171. https://doi.org/10.14710/jsmo.v13i2.13408

Indarjono, H. (2021). Wawancara penelitian Tesis dengan Kepala KPPBC TMP Ngurah Rai.

Julia Hapsari, D. (2019). Implementasi Pembangunan Zona Integritas Menuju Wilayah Bebas Dari Korupsi Dan Wilayah Birokrasi Bersih Dan Melayani Di BBWS Pemali Juana Semarang. JURNAL ILMU ADMINISTRASI PUBLIK, 1, 25-42.

Kementrian Keuangan Republik Indonesia. (n.d.). Nilai-nilai Kementerian Keuangan. https://www.kemenkeu.go.id/profil/nilai-nilai-kementerian-keuangan/

Korupsi, K. P. (2020). E-learning.KPK.go.id. E-learning.KPK.go.id 
Mursid, A. H. (2017). HUMAN CAPITAL MANAGEMENT VS HUMAN RESOURCES MANAGEMENT. http://www.andihanifmursid.com/2017/02/human-Capital-Management-vs-Human.html.

Nuaba, I. N. (2020). Wawancara penelitian tesis dengan Bidang Penguatan Kualitas Pelayanan Publik.

Peraturan Menteri Pendayagunaan Aparatur Negara dan Reformasi Birokrasi Republik Indonesia Nomor 52 Tahun 2014. (n.d.). tentang Pedoman Pembangunan Zona Integritas Menuju Wilayah Bebas Korupsi dan Wilayah Birokrasi Bersih dan Melayani di Lingkungan Instansi Pemerintah.

Peraturan Pemerintah No 101 Tahun 2000. (n.d.). Tentang Pendidikan Dan Pelatihan Jabatan Pegawai Negeri Sipil. In Peraturan Pemerintah Republik Indonesia (Vol. 1999, Issue September, pp. 1-2).

Peraturan Presiden Nomor 81 Tahun 2010. (n.d.). Tentang Grand Design Reformasi Birokrasi 2010 - 2025 (Vol. 1999, Issue September, pp. 1-2). http://www2.pom.go.id/public/hukum_perundangan/pdf/Pengamanan rokok bagi kesehatan.pdf

Pranoto, E. (2018). Pembangunan Sistem Hukum Ekonomi Indonesia Berlandaskan Pada Nilai Pancasila Di Era Globalisasi. Spektrum Hukum, 15(1), 89. https://doi.org/10.35973/sh.v15i1.1111

Prasojo, L. D., Mukminin, A., \& Mahmudah, F. N. (2017). Manajemen Human Capital dalam Pendidikan (Issue November).

Priono, A. B. (2020). Wawancara penelitian tesis dengan Bidang Penataan sistem Manajemen SDM.

Purnomo, K. H. (2020). Wawancara penelitian tesis dengan Bidang Manajemen Perubahan.

Sudana, B. P. A. (2021). Wawancara penelitian Tesis dengan bidang Penguatan Pengawasan.

Suhascaryo, E. (2021). Webinar assesment center.

Sukmana, D. T. dan, \& Indarto, I. (2018). Pengaruh Kepemimpinan Dan Integritas Terhadap Kinerja Anggota Polisi Melalui Kepuasan Kerja Sebagai Variabel Intervening. Jurnal Riset Ekonomi Dan Bisnis, 11(2), 128. https://doi.org/10.26623/jreb.v11i2.1081

Sukoco, D. P. dan I. (2017). Pendekatan Human Capital untuk pengelolaan sumber daya manusia yang lebih produktif. Jurnal AdBispreneu, 2(1), 93-104.

Sunarno. (2020). Reformasi Birokrasi Dalam Rangka Mewujudkan Good Governance Di Indonesia. Jurnal Wacana Kinerja: Kajian Praktis Akademis Kinerja Dan Administrasi Pelayanan Publik, 10(2), 7-16.

Wahyudi, D. (2017). INTEGRITAS: Nilai Kementerian Keuangan yang Utama. Https://www.djkn.kemenkeu.go.id/kamus-kompetensi/baca/1/INTEGRITAS-Nilai-KementerianKeuangan-Yang-Utama.html. https://www.djkn.kemenkeu.go.id/kamuskompetensi/baca/1/INTEGRITAS-Nilai-Kementerian-Keuangan-yang-Utama.html

Wisuda, J. R. (2020). Wawancara penelitian tesis dengan Bidang Penataan Tata Laksana. 